\title{
Editorial
}

\section{The Council of Europe's Responses to the Decay of the Rule of Law and Human Rights Protections: A Comparative Appraisal}

\author{
Başak Çalı \\ Co-Director, Centre for Fundamental Rights; Professor of International Law, \\ Hertie School of Governance, Berlin, Germany \\ cali@hertie-school.org \\ Esra Demir-Gürsel | ORCID: oooo-0oo2-5063-535X \\ Georg Forster Postdoctoral Research Fellow at Humboldt-Universität zu \\ Berlin, Faculty of Law, Berlin, Germany \\ esra.demir-guersel@rewi.hu-berlin.de
}

\begin{abstract}
This article introduces the Special Issue on 'The Responses of the Council of Europe to the Decay of the Rule of Law and Human Rights Protections'. The Council of Europe $(\mathrm{CoE})$, a unique international organisation with its commitment to protect and promote human rights, the rule of law, and democracy, has been severely tested by the spread and consolidation of trends posing systemic threats to its foundational goals. The authors of this Special Issue assess how the European Court of Human Rights, the Venice Commission, the Parliamentary Assembly, the Committee of Ministers, and the office of the Secretary General have addressed systemic threats to the foundational principles of the organisation in the last decade. The Special Issue finds that the respective legal-institutional features and capacities of the CoE organs as well as the constraining influence of the broader political context in Europe on
\end{abstract}


them vary significantly, hampering the CoE's ability to produce timely, consistent, and co-ordinated responses against systemic threats.

\section{Keywords}

democratic backsliding - rule of law backsliding - Council of Europe - European Court of Human Rights - Venice Commission - Parliamentary Assembly of the Council of Europe - Committee of Ministers of the Council of Europe - Secretary General of the Council of Europe

\section{Introduction}

The Council of Europe ( $\mathrm{CoE}$ ) is a unique international organisation. Arising from the destructive consequences of Nazism and fascism in Europe, the Second World War, it originally brought together a small number of Western European states under a common commitment to human rights, the rule of law, and democracy. ${ }^{1}$ This common ground has gradually taken on a dense and institutionalised form through the ever-growing acquis of the CoE institutions. ${ }^{2}$ In the aftermath of the Cold War, the CoE enlarged dramatically by extending its membership to east and central Europe and Russia. ${ }^{3}$ Through this expansion, the CoE has taken on a new role: to act as a facilitator in the process of entrenching and supporting liberal democracies across Europe. The mood at the CoE at the end of the 199 os was that of pragmatism, and optimism that all of Europe would ultimately be governed by liberal democratic states. ${ }^{4}$

1 See, the Preamble of the Statute of the Council of Europe. The original members of the CoE were Belgium, Denmark, France, Ireland, Italy, Luxembourg, the Netherlands, Norway, Sweden, and the United Kingdom. Short after, Greece (1949), Turkey (1950), Germany (1950), Iceland (1950), and Austria (1956) also become members of the CoE. See, B Wassenberg, History of the Council of Europe (Council of Europe Publishing 2013).

2 See, S Schmahl and M Breuer (eds), The Council of Europe: Its Law and Policies (Oxford University Press 2017).

3 Czech Republic (1992), Bulgaria (1992), Slovak Republic (1992), Hungary (1992), Poland (1993), Romania (1994), Slovenia (1994), Lithuania (1995), Estonia (1996), Albania (1996), Andorra (1996), Latvia (1997), Moldova (1997), FYrom (1997), Ukraine (1997), Croatia (1997), Russian Federation (1998), Georgia (1999), Armenia (2002), Azerbaijan (2002), Bosnia and Herzegovina (2002), Serbia (2004), and Montenegro (2004). See, Council of Europe, 'Chart of Signatures and Ratifications of Treaty 005': <https://www.coe.int/en/web/conventions/ full-list/-/conventions/treaty/oo5/signatures?p_auth=vFZ7AeW4>.

$4 \quad$ PA Jordan, 'Does Membership Have its Privileges? Entrance into the Council of Europe and Compliance with Human Rights Norms' (2003) 25 Human Rights Quarterly 66o. But also 
It was in this post-Cold War enlargement process, too, that the CoE refurbished its institutional architecture to support its newly found role as an enabler of transition to liberal democracy. The European Commission for Democracy through Law (Venice Commission - vc) was established in 1990. ${ }^{5}$ The Parliamentary Assembly of the CoE (PACE) established its Monitoring Committee primarily to assist new members of the CoE in 1997.6 The European Court of Human Rights (ECtHR, or the Court) was transformed into a full time and compulsory court in 1998. ${ }^{7}$ The CoE Commissioner for Human Rights was established in $1999 .{ }^{8}$ Finally, the Committee of Ministers of the Council of Europe (СM) has embarked upon a reform process to institutionalise its monitoring of the judgments of the ECtHR, beginning in the early 20oos. ${ }^{9}$

Today, there are important reasons to question the optimism of the 199os and the ability of the $\mathrm{CoE}$ and its institutions to support the entrenchment of human rights, the rule of law, and liberal democracy in its member states. ${ }^{10}$ The last decade in Europe has witnessed wide ranging policies and practices alongside legal and constitutional reforms in a number of CoE member states that openly run counter to the foundational principles upon which the $\mathrm{CoE}$ and the European Convention on Human Rights (ECHR, or the Convention) rest. Political scientists identify a deterioration of democratic indicators in more than half of the CoE member states: some of these, namely Hungary, Poland, Romania, Serbia, Turkey, and Ukraine, are counted among the ten countries in

see, M Janis, 'Russia and the "Legality" of Strasbourg Law' (1997) 8(1) European Journal of International Law 93.

5 See, Committee of Ministers, 'On a Partial Agreement Establishing the European Commission for Democracy Through Law' (10 May 199o) Resolution(9o)6.

6 Committee on the Honouring of Obligations and Commitments by Member States of the Council of Europe, 'Monitoring Committee: Work Overview' (15 June 2020) AS/Mon/ $\operatorname{Inf}(2020) 12$.

7 Protocol No 11 to the Convention for the Protection of Human Rights and Fundamental Freedoms, Restructuring the Control Machinery Established Thereby (adopted 11 May 1994, entered into force 1 November 1998) ETS 155.

8 The office of the Commissioner for Human Rights was instituted in 1999 following the decision of the Heads of State and Government of the member states of the Council of Europe at their Second Summit in 1997. See, Committee of Ministers, 'On the Council of Europe Commissioner for Human Rights' (7 May 1999) Resolution (99)5o.

9 Committee of Ministers, 'On Judgments Revealing an Underlying Systemic Problem' (12 May 2004) $\operatorname{Res}(2004) 3$.

10 Also see, W Benedek, 'The Effectiveness of the Tools of the Council of Europe Against Democratic Backsliding: What Lessons Can Be Learned from the "Greek Case” (2020) 2 Austrian Law Journal 1, 1-2. 
the world undergoing 'democratic backsliding." ${ }^{11}$ Some CoE members are no longer defined as a 'democracy', but rather as 'hybrid regimes' (such as Russia) or as 'non-democracy' (such as Azerbaijan). ${ }^{12}$ Whilst regime type categorisation or the scores of level of democracy may differ from one study to another, ${ }^{13}$ the overall evidence underlines that member states of the $\mathrm{CoE}$ are part of a global trend, understood as the erosion of liberal democratic institutions and the rule of law..$^{14}$ The 2021 State of Democracy, Human Rights and the Rule of Law Report by the Secretary General of the $\mathrm{CoE}(\mathrm{sG})$ confirms the existence of 'a clear and worrying degree of democratic backsliding' among member states, and stresses that this has only further deteriorated over the last year with the outbreak of the Covid-19 pandemic. ${ }^{15}$ Moreover, some aspects of this transformation cut across the so-called liberal-illiberal divide in European democracies, as seen in the fields of migration control and anti-terrorism. ${ }^{16}$

Against the backdrop of the political and legal transformations in Europe in the last decade, this Special Issue focuses on the question of whether the $\mathrm{CoE}$ is adequately responsive to the decay of a shared commitment to liberal democracy, the rule of law, and human rights in its member states. In so doing, the Special Issue offers a comparative investigation of how the organs of the CoE have defended the foundational principles of the organisation, the rule of law, human rights, and democracy, when they were confronted with laws, policies, and actions that run counter to, and pose systemic threats to, these

11 See, IDEA, 'The Global State of Democracy 2019 - Addressing the Ills, Reviving the Promise' (2019): <https://www.idea.int/sites/default/files/publications/the-global-state-ofdemocracy-2019.pdf $>, 212$.

12 Ibid 211.

13 Democracy Index, for instance, relies on four regime types: democracies, flawed democracies, hybrid regimes, and authoritarian regimes. None of the Eastern European members of the $\mathrm{CoE}$ are defined as 'democracies' in its 2019 report. Among them, Poland and Hungary are considered flawed democracies (along with some Western European democracies including Malta, Belgium, Italy, Cyprus, and Greece), while the report defines Turkey as a 'hybrid regime', and Russia and Azerbaijan as 'authoritarian regimes'. See, The Economist Intelligence Unit, 'Democracy Index 2020: In Sickness and in Health?' (2021): <https:// www.eiu.com/n/campaigns/democracy-index-2020/>. Another meta data index ranked Azerbaijan, Russia, and Turkey as 'not free', and Armenia, Georgia, Hungary, and Ukraine as 'partly free' in 2020. See: <https://freedomhouse.org/countries/freedom-world/scores >. D Runciman, How Democracy Ends (Profile Books 2018).

15 Secretary General of the Council of Europe, 'State of Democracy, Human Rights, and the Rule of Law: A Democratic Renewal for Europe' (Council of Europe, 2021): <https://www. coe.int/en/web/secretary-general/report-2021\#page-o>, 5 .

16 Secretary General of the Council of Europe, 'State of Democracy, Human Rights and Rule of Law: Populism - How Strong are Europe's Checks and Balances?' (Council of Europe, 2017): $<$ https://rm.coe.int/state-of-democracy-human-rights-and-the-rule-of-law-populism-howstron $/ 168070568 f>, 4$. 
principles. The Special Issue focuses on five organs of the CoE: the ECtHR, the VC, the PACE, the CM, and the SG.

\section{Systemic Threats to the Core Principles of the CoE}

To assess the responsiveness of the $\mathrm{CoE}$ institutions to threats to its foundational principles, it is first necessary to distinguish systemic threats from what may be termed non-systemic threats or violations of human rights in $\mathrm{CoE}$ member states. The ECHR is violated frequently by all of its member states across all of the rights that it protects. ${ }^{17}$ Not all of these violations, however, may be understood as systemic threats to the foundational principles of the CoE. ${ }^{18}$

Existing scholarship offers helpful concepts and indicators to differentiate systemic threats from non-systemic threats, and to differentiate between the different types of systemic threats posed by different states to the foundational principles of the CoE. ${ }^{19}$

Two oft used concepts to frame a threat as systemic, 'democratic backsliding' and 'the rule of law backsliding', are particularly pertinent in this context. Scholars define democratic backsliding as 'the state-led debilitation or elimination of any of the political institutions that sustain an existing democracy'. ${ }^{20}$ Laurent Pech and Kim Lane Scheppele define 'the rule of law backsliding' as

the process through which elected public authorities deliberately implement governmental blueprints which aim to systematically weaken, annihilate or capture internal checks on power with the view of dismantling the liberal democratic state and entrenching the long-term rule of the dominant party. ${ }^{21}$

Common to the conceptualisations of democratic backsliding and the rule of law backsliding is the identification of deliberate and purposeful action against

17 ECtHR, 'Violations by Article and by State': <https://echr.coe.int/Documents/Stats_ violation_1959_2019_ENG.pdf>.

18 This, however, is not to suggest that other types of violations concern less severe interventions on human lives.

19 For a survey on the conceptual field, see, TG Daly, 'Democratic Decay: Conceptualising an Emerging Research Field' (2019) 11 Hague Journal on the Rule of Law 9.

$20 \quad$ N Bermeo, 'On Democratic Backsliding' (2016) 27(1) Journal of Democracy 5, 5.

21 L Pech and KL Scheppele, 'Illiberalism Within: Rule of Law Backsliding in the EU' (2017) 19 Cambridge Yearbook of European Legal Studies 3. 
the core liberal democratic institutions, political or judicial, by those in power. As Nancy Bermeo underlines, the term 'backsliding' implies 'a wilful turning away from an ideal'. ${ }^{22}$ Pech and Scheppele, too, view retrogression that is the undoing of previous achievements in relation to the rule of law in as an important marker of the rule of law backsliding. Identifying retrogression through deliberate strategies to undermine liberal democratic institutions, therefore, helps to differentiate the rule of law backsliding from non-systemic human rights violations within Europe, where, in the case of the latter, structural rule of law deficiencies, inadequate legal frameworks or policies institutional incapacity, or lack of knowledge may be the cause of the under-protection of human rights. ${ }^{23}$

A common feature of the current trends pointing to a move away from liberal democratic ideals and institutions is the justificatory role of right-wing populist ideologies in repurposing domestic laws and institutions. In the context of Poland, Sadurski, for example, identifies the key threat as that of 'anti-constitutional populist backsliding. ${ }^{24}$ The populist ideological justification for repurposing domestic law and institutions claims to do this to protect the democratic will of 'authentic people' against non-authentic human rights claims. ${ }^{25}$ These claims are often attributed to minorities, migrants, LGBTQI+ individuals, and women in many of these countries, thus also giving way to a 'human rights backsliding' alongside the rule of law and democratic backsliding. In turn, opposition politicians, political activists, journalists, civil society, and sometimes also migrants, are labelled as 'terrorists'. When ruling regimes mobilise such populist discourses, the domestic repurposing of fundamental rights and institutions is presented in the name of advancing the democratic will of the people, and the rights of what are constructed as the 'authentic citizens' against internal or external threats. ${ }^{26}$

The literature further offers ways of distinguishing between types of systemic threats coming from different states to the CoE principles. Sadurski, for

22 Bermeo (n 20) 6.

23 Pech and Scheppele (n 21) 11-12.

24 W Sadurski, Poland's Constitutional Breakdown (Oxford University Press 2019) 28.

25 JW Müller, 'Populism and Constitutionalism', in The Oxford Handbook of Populism, CR Kaltwasser et al (eds), (Oxford University Press 2017) 591, 593, defining the claim to be the sole proper representative of the 'authentic people' as populism's core claim.

26 Bermeo (n 20) 11; KL Scheppele, 'Autocratic Legalism' (2018) 85 University of Chicago Law Review 545. Even if this populist ideological aspect is also increasingly widespread amongst political parties and social movements in a larger number of CoE member states, in many of these countries the institutions such as the judiciary, national parliament, independent media, and civil society (still) retain their democratic functions. In what are referred to as 'backsliding states', however, these institutions have increasingly lost their ability and capacity to enforce the CoE's foundational principles in the domestic setting. 
example, emphasises that the threat to liberal democracy in the case of Poland (and also Hungary) is different from cases such as Russia, Moldova, Belarus, or Azerbaijan, because no comparable 'democratic progress' has been achieved in these countries. ${ }^{27}$ As such, whilst a larger set of CoE states can be characterised as backsliding from the democracy and rule of law ideals of the CoE by way of deliberate action, systemic threats can be understood to be different in kind: some are systemic threats because the commitment to democratic progress has been abandoned and is no longer taken seriously, whilst others are systemic threats because what is at stake is the undoing of tangible liberal democratic gains. The fact that the countries which can be discussed in the latter category are also members of the European Union (EU) further brings to the fore the dual form of systemic threats, where the foundational principles of both the CoE and the EU are at stake. ${ }^{28}$

As a protracted accession country to the EU, Turkey, for example, might be assessed under a number of these categories, both as a country with no major democratic progress and a case of retrogression, given the significant reforms that were prompted by its accession process to the EU, in particular in the early 20oos. ${ }^{29}$ However, regardless of whether a country's situation is analysed as retrogression or as a failed transition to liberal democracy, institutional outcomes in both situations have similar features, ${ }^{30}$ a striking one being the erosion of public institutions that are indispensable for the rule of law, democracy, and human rights protections by 'repurposing' them through 'laws, constitutional revision, and institutional reforms, ${ }^{31}$ and another being the exclusion or vilification of some groups or individuals as internal or external threats.

Contributions to this volume reflect the diversity of benchmarks discussed above when addressing systemic threats to the foundational principles of the CoE in their assessments. In his contribution, Mikael Rask Madsen employs the distinction between consolidated and non-consolidated democracies when studying the operation of the Court's deference case law and proceduralism.

27 Sadurski (n 24) $27-28$.

28 See,EuropeanCommission, 'Rule of Law Report2020' (3oSeptember2020): <https://ec.europa. eu/info/publications/202o-rule-law-report-communication-and-country-chapters_en>.

29 This ambivalent status of Turkey is reflected in the Special Issue through its alignments either with Russia (as in the contributions by E Demir-Gürsel and MR Madsen in this Special Issue) or with Poland and Hungary (as in the contribution by E Turkut in this Special Issue).

30 Scheppele (n 26).

$31 \quad$ Ibid $573-74$. On the centrality of legal reforms and legal means in the consolidation of authoritarian modes of governance, also see, OO Varol, 'Stealth Authoritarianism' (2015) 100 Iowa Law Review 1673; D Landau, 'Abusive Constitutionalism' (2013) 47 UC Davis Law Review 189; B Bugarič, 'Central Europe's Descent into Autocracy: On Authoritarian Populism' (20182019) CES Harvard Open Forum Paper Series 5, 14-21. 
Emre Turkut appraises the track record of the VC in its responses to Turkey, Poland, and Hungary, which he defines as instances of rule of law backsliding. In their analysis of the PACE, Alice Donald and Anne-Katrin Speck focus on the responses of the PACE through its employment of monitoring procedures in Poland, Hungary, Turkey, and Azerbaijan, thereby combining countries that have been categorised as the rule of law and democracy backsliders and those which have reversed transitions from democratisation. Başak Çalı studies responses to systemic threats through the lens of the Article 18 judgments of the ECtHR. She analyses the responses of the member states and the $\mathrm{CM}$ to Article 18 judgments by studying the monitoring of the execution of these judgments with regard to Russia, Moldova, Georgia, Ukraine, Turkey, and Azerbaijan. Finally, in her study of the SG, Esra Demir-Gürsel analyses the responses by the SG to systemic breaches of the ECHR and Article 3 of the Statute of the CoE in the context of Russia's annexation of the Crimea in 2014 and Turkey's state of emergency measures in the aftermath of the failed coup d'etat of July 2016.

\section{Systemic Threats and Responsive Agility of the Council of Europe} Organs

The CoE organs are not short of institutions and tools to respond to the member states' breaches of the core principles of the organisation. These tools range from legal mechanisms to soft sanctions, monitoring, political pressure, and naming and shaming. ${ }^{32}$ As a last resort, Article 8 of the Statute of the CoE also vests the CM with the power to expel member states in case of serious violations of its Article 3, which requires member states to sincerely comply with the principles of the rule of law and the enjoyment of human rights, and to collaborate in the realisation of the goals of the $\mathrm{CoE} \cdot{ }^{33}$ Being a last resort, appeal to this provision is, in principle, only possible when the other available means fall short of compelling a member state to comply with its core

32 For an overview, see, N Muižnieks, 'The Council of Europe's Response to Recent Democratic Backsliding', in European Yearbook on Human Rights 2019, Philip Czech and others (eds), (Intersentia 2019). Also see, W Benedek, 'Are the Tools of the Council of Europe Sufficient to Protect Human Rights, Democracy and the Rule of Law from Backsliding?' (2020) 1(2) European Convention on Human Rights Law Review 151; Benedek (n 10); J Polakiewicz and JK Kirchmayr, 'Sounding the Alarm: The Council of Europe As the Guardian of the Rule of Law in Contemporary Europe', in Defending Checks and Balances in EU Member States, A von Bogdandy and others (eds), (Springer 2021) 361.

Statute of the $\operatorname{CoE}\left(\mathrm{n}_{1}\right)$. 
obligations. ${ }^{34}$ To date, it has never been used by the CoE. ${ }^{35}$ More importantly, the CoE showed its unwillingness to use it even in the case of Russia's failure to submit its credentials and non-payment of its membership contribution as a reaction to the PACE's sanctions that were imposed as a response to the unlawful annexation of the Crimea. This evident unwillingness has rendered 'the threat of activating Article 7 [sic] of the Statute largely ineffective as a mechanism to address backsliding. ${ }^{36}$ The wide range of tools, beyond expulsion, that are at the disposal of the $\mathrm{CoE}$ organs to respond to systemic threats to the foundational principles of the organisation, however, vary significantly from one institution to the other, both in terms of the type of the output and the speed with which these may be deployed.

The ECtHR addresses systemic threats as it handles all other human rights violation claims: through its judicial procedures, namely interim measures, decisions and judgments. Furthermore, the judgments of the ECtHR are capable of identifying the root causes of violations and pronouncing individual and general remedies to address them under Article 46 of the ECHR or under its pilot judgment procedure. In the last decade, the ECtHR has addressed a wide range of 'systemic threat' cases, including, for example, the interventions impairing the independence of the judiciary, ${ }^{37}$ politically motivated prosecution of opposition politicians, ${ }^{38}$ journalists, ${ }^{39}$ and activists, ${ }^{40}$ and the interventions on the functioning of political parties. ${ }^{41}$ In some of these cases the ECtHR has also resorted to Article 18 of the ECHR, finding that the influence of political and economic ulterior motivations played a decisive role in bringing

34 K Dzehtsiarou and DK Coffey, 'Suspension and Expulsion of the Council of Europe: Difficult Decisions in Troubled Times' (2019) 68(2) International \& Comparative Law Quarterly 443, 447.

35 See, ibid.

36 Muižnieks (n 32$) 9$.

37 E.g., Baka v Hungary [GC] 20261/12 (ECtHR, 23 June 2016); Alparslan Altan v Turkey 12778/17 (ECtHR, 16 April 2019); Xero Flor w Polsce sp. Z o.o. v Poland 4907/18 (ECtHR, 7 May 2021).

38 E.g., Ilgar Mammadov v Azerbaijan (No 2) 919/15 (ECtHR, 16 November 2017); Navalnyy v Russia [GC] 2958o/12 and others (ECtHR, 15 November 2018); Selahattin Demirtaş v Turkey (No 2) [GC] 14305/17 (ECtHR, 22 December 2020).

39 E.g., Fatullayev v Azerbaijan 40984/o7 (ECtHR, 22 April 2010); Sabuncu and Others $v$ Turkey 23199/17 (ECtHR, 10 November 2020).

40 E.g., Rasul Jafarovv Azerbaijan 69981/14 (ECtHR, 17 March 2016); Aliyevv Azerbaijan 68762/14 and 71200/14 (ECtHR, 20 September 2018); Kavala v Turkey 28749/18 (ECtHR, 10 December 2019).

41 E.g., Republican Party of Russia v Russia 12976/o7 (ECtHR, 12 April 2011); Party for a Democratic Society (DTP) and Others $v$ Turkey $3840 / 10$ (ECtHR, 12 January 2016). 
about human rights violations. ${ }^{42}$ It also received inter-state complaints, most notably those arising from the Russian aggression against Ukraine..$^{43}$ Recently, the ECtHR has delivered an interim measure with respect to the armed conflict between Armenia and Azerbaijan. ${ }^{44}$

Although the ECtHR assigned priority to certain 'systemic threat' cases, ${ }^{45}$ it is hard to argue that it has responded to all such cases with the urgency they demanded.$^{46}$ Moreover, as shown by Madsen in his contribution, the Court has become 'a more limited and in some instances a less accessible Court' in the past decade. Studying the role of subsidiarity in calibrating responses, Madsen identifies 'a retreat' on the part of the Court vis à vis both 'consolidated democracies' and 'non-consolidated' democracies, including 'authoritarian democracies'. While in the case of 'the consolidated democracies' this retreat amounts to the acceptance of a greater diversity in standards, in the case of 'decaying

42 See, Başak Çalı in this Special Issue.

43 See, Ukraine v Russia (re Eastern Ukraine) 8o19/16; Ukraine v Russia (re Crimea) 20958/14; Ukraine $v$ Russia (II) 4380o/14, on the alleged abduction of some children and their transfer to Russia; Ukraine $v$ Russia (VII) $38334 / 18$, on the politically motivated detention and prosecution of Ukrainian citizens; Ukraine $v$ Russia (VIII) 55855/18, on the events on Kerch Strait in November 2018.

44 See, ECtHR, 'The Court Grants an Interim Measure in the Case of Armenia v Azerbaijan' (30 September 2020) ECHR 265 (2020): <https://hudoc.echr.coe.int/app/conversion/ pdf/?library=ECHR\&id $=003-6809725-9108584 \&$ filename $=$ Court $\% 27 \mathrm{~s}+$ decision + on + th e+request+for+interim+measure+lodged+by+Armenia+against+Azerbaijan.pdf $>$. On 6 October 2020, the Court extended the interim measures 'to all States directly or indirectly involved in the conflict, including Turkey'. See, ECtHR, 'The Court's Decision on the Request for an Interim Measure Lodged by Armenia Against Turkey' (6 October 2020) ECHR 276 (2020): <https://hudoc.echr.coe.int/app/conversion/pdf/?library=ECHR\&id=oo3-6816855$9120472 \&$ filename $=$ Court $\% 27 \mathrm{~s}+$ decision + on + the + interim + measure + request + introduced $+b$ $\mathrm{y}+$ Armenia+against + Turkey.pdf $>$.

45 E.g., ECtHR, 'Recently Communicated Priority Cases on Detained Journalists in Turkey' (15 November 2017) ECHR 346 (2017): <https://hudoc.echr.coe.int/app/conversion/ pdf/?library=ECHR\&id=003-59166o6-7553343\&filename=Recently\%2ocommunicated $\% 20$ priority\%2ocases\%2oon\%2odetained\%2ojournalists\%20in\%2oTurkey.pdf>; ECtHR, 'ECtHR Gives Notification to Poland of Five Cases Concerning Alleged Lack of Judicial Independence' (10 May 2021) ECHR 140 (2021): <https://hudoc.echr.coe.int/app/conversion/ pdf/?library=ECHR\&id=003-7017191-9464410\&filename=Notification + of + five + cases + concer ning+Poland.pdf $>$.

46 See, Başak Çall, 'Autocratic Strategies and the European Court of Human Rights' (2021) 2 European Convention on Human Rights Law Review 11, 14-15; Esra Demir-Gürsel, 'The Limits of the European Court of Human Rights vis-à-vis Contestation and Authoritarianism: Concluding Observations', in The European Court of Human Rights: Current Challenges from Historical Perspective, Helmut Philipp Aust and Esra Demir-Gürsel (eds), (Edward Elgar Publishing 2021) 244, 259. 
democracies', it has curbed its ability to arrest the deterioration in the domestic protection of human rights, the rule of law, and democracy.

The vc, the advisory body of the CoE on constitutional and legal matters, is well placed to address systemic threats to the rule of law and democracy through its opinions drafted upon the requests from the CM, the PACE, the Congress of Local and Regional Authorities of Europe, the SG, states, or international organisations participating in its work, such as the OSCE or the EU.47 Even though it cannot immediately react to rapid developments that jeopardise the rule of law, human rights, and democracy, ${ }^{48}$ the vC was able to prepare in-depth expert analysis over the course of some months in the last decade. ${ }^{49}$ However, for its advisory opinions to produce real outcomes, not only the cooperation of the relevant states ${ }^{50}$ but also institutional support by other $\mathrm{CoE}$ organs is needed. ${ }^{51}$

Turkut's contribution demonstrates that the vC's responses, unpacking and identifying serious threats posed by several legislative and constitutional amendments in Turkey, Hungary, and Poland, were not translated into actual change, as these states refused to engage in a dialogue with the VC and its recommendations. On the other hand, as Turkut highlights, PACE's decisions to reopen the full monitoring with regard to Turkey and Poland significantly drew from the vc's work. Conversely, however, the impact of its opinions on the Court has been curtailed by the latter's partial recourse thereto. The de facto retreat of the Court in addressing cases from countries with well-documented concerns of the rule of law and democratic backsliding, as identified by Madsen is, therefore, echoed in Turkut's findings on the selective use of vC opinions by the Court.

The PACE provides an important forum for deliberating on systemic threats. The tools at its disposal to address such severe threats vary from the re-opening of full monitoring to holding urgent debates or passing resolutions, from the suspension of a delegation's participation and representation rights to the non-ratification of a delegation's credentials. However, as of 2019, the PACE has given up its power to deploy some of its sanctions by changing its Rules

47 Venice Commission, 'Adopting the Revised Statute of the European Commission for Democracy Through Law' (21 February 2002) CDL (2002) 27, Article 3(2).

48 Muižnieks (n 32$) 12$.

49 But for a critique of the vc for its failure to pay due attention to the political context that renders its recommendations unlikely to have a real impact, see, R Uitz 'What Does the Spring Bring for the Rule of Law in Europe?' (Verfassungsblog, 6 April 2019): <https:// verfassungsblog.de/what-does-the-spring-bring-for-the-rule-of-law-in-europe/>.

$50 \quad$ Sadurski (n 24) 196.

$5^{1} \quad$ Benedek (n 32) 154. 
of Procedure..$^{52}$ In February 2021, a new procedure, which was introduced to respond to serious violations of states' statutory obligations in coordination with the CM, has become operational. ${ }^{53}$ This new procedure is ostensibly to ensure coordinated action on the part of the PACE and the CM, and thereby to respond to states' serious breaches of their statutory obligations in a more effective manner. It may, however, equally function as another hurdle for the PACE to use its sanctions in the context of the rule of law backsliding and may rather serve as a tool for collective restraint. ${ }^{54}$

It should also be noted that the PACE is a political body, which, by design, enables national members of parliaments to articulate opposing political positions on systemic threats to CoE principles. In their contribution, Donald and Speck highlight that the PACE has refrained from using sanctions and has increasingly become less equipped to appeal to sanctions vis à vis the rule of law backsliding. So far, it has limited itself with the reopening of the monitoring procedure to respond to cases of the rule of law backsliding. Having become 'the sole realistic means' to be used, Donald and Speck argue that monitoring attracted serious political controversies amongst parliamentarians, which have in turn rendered it a highly political and politicised form of response. While the alliances and oppositions along political and/or national lines caused a considerable delay in the reopening of the monitoring in the case of Poland, in others, such as Hungary, they enabled the states to evade the procedure.

The CM addresses systemic threats to the Convention system through its regular monitoring role of the execution of the monitoring of human rights judgments. Similar to the ECtHR, the contribution of the сM is slow as it only starts monitoring when a judgment becomes final. Furthermore, the CM only convenes four times a year and has to address a substantial backlog of

52 Parliamentary Assembly of the Council of Europe, 'Strengthening the Decision-Making Process of the Parliamentary Assembly Concerning Credentials and Voting' (25 June 2019) Resolution 2287 (2019).

53 Parliamentary Assembly of the Council of Europe, 'Modification of the Assembly's Rules of Procedure - Follow-up to Resolution 2319 (2020) on the Complementary Joint Procedure Between the Committee of Ministers and the Parliamentary Assembly in Response to a Serious Violation by a Member State of its Statutory Obligations' (26 January 2021) Resolution 2360 (2021).

54 A Donald and K Speck in this Special Issue. For an analysis of the new procedure and its possible impact, see, LR Glas, 'They Did it Again: Russia's Continued Presence in the PACE' (Strasbourg Observers, 23 February 2021): <https://strasbourgobservers.com/2021/02/23/ they-did-it-again-russias-continued-presence-in-the-pace/>. 
unimplemented cases. ${ }^{55}$ Despite these shortcomings, the см is capable of exerting political pressure on states, by way of organising cases that expose a systemic problem under enhanced supervision or issuing interim resolutions. The $\mathrm{cm}$ also has the ability to initiate infringement proceedings against a state if that state is resisting the implementation of human rights judgments.

Studying the CM's responses to the Article 18 violations, Çalı shows that the CM's stance has improved over time from indifference to heightened responsiveness, in particular concerning the implementation of urgent individual measures, such as requests for the release of detainees. The см has made use of a diverse set of tools, ranging from making specific demands for governments to implement Article 18 judgments, to regular monitoring of progress. It even made use of its powers under Article 46(4) of the Convention with regard to Azerbaijan in the case of the Azeri opposition politician, Ilgar Mammadov. ${ }^{56}$ Çalı also shows that there has been a close relationship between the CM's responsiveness and the increase in the involvement of legal representatives, members of civil society, and, more recently, the CoE Commissioner for Human Rights in the process of the execution of Article 18 judgments.

Finally, the SG, as the political head of the organisation, may address serious threats through rapid reactions in the form of public statements or letters to the relevant governmental bodies, as well as facilitating the assistance of relevant CoE bodies, including by requesting advisory opinions from the vc. The SG is also able to directly communicate and negotiate with the agents of the state concerned and also other relevant political actors. Furthermore, Article 52 of the ECHR endows the SG with the power to request that the member states submit explanations as to how their domestic laws ensure the effective implementation of the Convention. ${ }^{57}$ Nevertheless, the SG is seen as constrained by the will of the member states and the prevailing tendencies in the см. ${ }^{58}$

Despite this, as Demir-Gürsel underlines in her contribution, the SG s might also have the power to shape the will of the member states and to create the

55 In 2019, the number of pending cases before the CM was 5,231, 1,245 of which were leading, and the remaining were repetitive cases. The first five states with most cases under enhanced supervision, respectively, were Russia (19 per cent), Ukraine (17 per cent), Turkey (11 per cent), Romania (8 per cent), and Italy (6 per cent). See, Committee of Ministers, 'Supervision of the Execution of the Judgments of the European Court of Human Rights 2019' (June 2020): <https://rm.coe.int/annual-report-2019/168ogec315<, 51-54, 72 .

56 Committee of Ministers, 'Execution of the Judgment of the European Court of Human Rights Ilgar Mammadov Against Azerbaijan' (25 October 2017) Interim Resolution CM/ $\operatorname{ResDH}(2017) 379$.

57 On the tools available to the SG, see, Muižnieks (n 32) 10-11; Benedek (n 10) 10.

$5^{8}$ Muižnieks (n 32) 29. 
necessary conditions to ensure certain types of reactions. The former SG of the CoE, who served from 2009 to 2019, was outspoken in his reports and public statements towards emerging threats to the rule of law, human rights, and democracy. ${ }^{59}$ His actions, however, remained cautious, diplomatic, and uneven. Demir-Gürsel further points out the role played by the former SG Thorbjørn Jagland in the postponement or the reversal of other CoE bodies' responses with regard to two critical events leading to systemic breaches of both the ECHR and the Statute of the CoE - namely, the reversal of the sanctions imposed by the PACE as a response to Russia's annexation of the Crimea and the postponement of the ECtHR's processing of applications concerning the state of emergency that followed the failed coup d'état in Turkey.

\section{Conclusion}

The articles in the Special Issue show that a wide range of responses have been produced by the CoE organs in response to what have been assessed as systemic threats to the foundational principles of the CoE. These responses range from judgments (including Article 18 judgments), the initiation of monitoring procedures and infringement proceedings, the delivery of legal opinions, public debates, and resolutions, to diplomatic interventions. The robustness, swiftness, and effectiveness of these responses, however, vary. Turkut's study shows that the vc has strongly criticised developments that undermine the rule of law consistently. Çalı shows that the collective action in response to the execution of Article 18 judgments by the CM has intensified over time and has led to securing individual measures in some of the Article 18 cases under its supervision. Demir-Gürsel's study of the office of the SG, however, shows that the diplomatic interventions by the SG have stalled, slowed down, or reversed (potential) processes before the PACE and the ECtHR. Madsen points to the systemic effects of subsidiarity on the responses of the ECtHR to processes of autocratisation, underlining that the ECtHR's structural emphasis on subsidiarity may have constrained, toned down, and delayed its responses to systemic threats. Finally, the study by Donald and Speck shows how the PACE's

59 E.g., Report by the Secretary General (2017) (n 16); Secretary General of the Council of Europe, 'State of Democracy, Human Rights, and the Rule of Law: Roles of Institutions - Threats to Institutions' (Council of Europe, 2018): <https://edoc.coe.int/en/an-overview/7584-stateof-democracy-human-rights-and-the-rule-of-law-5th-report-role-of-institutions-threats-toinstitutions.html>. 
responses have not been able to escape politicisation and polarisation between the parliamentarians.

This overview of the CoE's responses through its organs indicates that the $\mathrm{CoE}$ has failed to produce strong, timely, and co-ordinated responses against systemic threats understood through the prism of the decay of the rule of law and human rights protections in Europe. In some cases, such as Hungary and Poland, the CoE organs simply failed to support each other by acting as a collective body. In others, such as Russia, their responses have effectively undermined each other or, as in the case of Turkey, in some instances they did not simply fail to produce a single voice but their responses took the form of an exercise of coordinated restraint. The case of Azerbaijan, where both the CM and the former SG went furthest in their responses, has remained an outlier, which does not rectify the overall failure of the CoE to produce a coordinated and strong response to the decay of the rule of law and human rights among its member states.

Whilst the authors of the Special Issue lay out the institutional features and limits of these organs, they attribute these variations in the robustness of the responses not only to institutional agility and lack of co-ordination, but also to the constraining influence of the overall political context in Europe and the ability of the CoE organs to insulate themselves from these political constraints. Here, the Special Issue offers somewhat surprising results, and shows that being an expert organ is not enough to offer normatively robust responses. In this respect, whilst the vC seems to have insulated itself, the same observation cannot be made for the ECtHR and the SG. Equally, whilst the PACE emerges as the most politicised forum when responding to the systemic threats to the foundational principles of the $\mathrm{CoE}$, the $\mathrm{CM}$, despite its political nature, has gradually adopted a more vocal stance and increased the pressure that it exerts upon states, notwithstanding that this has remained limited to the execution of the 'bad faith violations' found under Article 18 of the Convention. 